\title{
Participatory health education on school (re)inclusion of the adolescent cancer survivor
}

\author{
Educação em saúde participativa sobre (re)inclusão escolar de adolescente sobrevivente de câncer
}

Educación sanitaria participativa sobre la (re)inclusión escolar de adolescente superviviente de cáncer

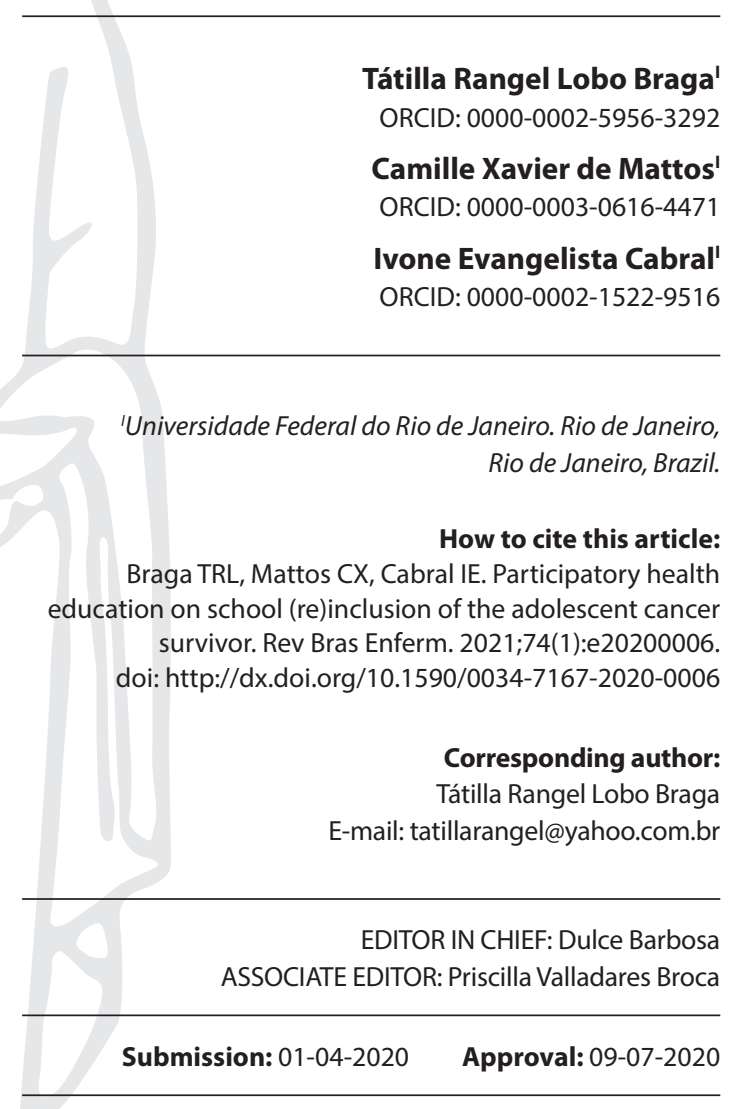

\begin{abstract}
Objectives: to analyze school (re)inclusion of an adolescent cancer survivor before/after participatory health education with adolescents. Methods: qualitative and participatory research that included data from the medical record of an adolescent rhabdomyosarcoma survivor and Talking Map dynamics (to diagnose the demand for learning and assess changes). The body-knowledge dynamics were applied in the educational intervention. In a public school in Rio de Janeiro, the adolescent (reference case) and nine people (four teachers and five teenagers) generated empirical materials, which became the content analysis objects. Results: strangeness to changes in an adolescent cancer survivor's body image, bullying, and acceptance were problematized in educational body-knowledge dynamics through relationships between changes and barriers to welcoming. The participatory educational process was essential in raising awareness by promoting re-inclusive actions. Conclusions: participatory-problematizing education contributed to constructing a new collective identity and improvement in school interaction among peers.
\end{abstract}

Descriptors: Adolescent; Cancer Survivors; Oncology Nursing; Health Education; Mainstreaming, Education.

\section{RESUMO}

Objetivos: analisar a (re)inclusão escolar de adolescente sobrevivente de câncer antes/ depois da educação em saúde participativa com adolescentes. Métodos: pesquisa qualitativa e participatória, que incluiu dados do prontuário de uma adolescente sobrevivente de rabdomiossarcoma e da dinâmica Mapa Falante (para diagnosticar a demanda de aprendizagem e avaliar mudanças). Na intervenção educativa, aplicou-se a dinâmica corpo-saber. Em uma escola pública do Rio de Janeiro, a adolescente (caso referência) e nove pessoas (quatro professores e cinco adolescentes) geraram materiais empíricos, objeto da análise de conteúdo. Resultados: o estranhamento às mudanças na imagem corporal de adolescente sobrevivente de câncer, bullying e aceitação foram problematizados na dinâmica educativa corpo-saber através das relações entre as mudanças e barreiras ao acolhimento. $O$ processo educativo participativo foi essencial na tomada de consciência ao promover ações reinclusivas. Conclusões: a educação participativa-problematizadora contribuiu para a construção de uma nova identidade coletiva e melhoria na convivência escolar entre pares.

Descritores: Adolescente; Sobreviventes de Câncer; Enfermagem Oncológica; Educação em Saúde; Inclusão Escolar.

\section{RESUMEN}

Objetivos: analizar la (re)inclusión escolar de adolescentes sobrevivientes de cáncer antes/ después de la educación participativa en salud con adolescentes. Métodos: investigación cualitativa y participativa, que incluyó datos de la historia clínica de un adolescente sobreviviente de rabdomiosarcoma y la dinámica Mapa Falante (para diagnosticar la demanda de aprendizaje y evaluar cambios). En la intervención educativa se aplicó la dinámica cuerpo-conocimiento. En una escuela pública de Río de Janeiro, el adolescente (caso de referencia) y nueve personas (cuatro profesores y cinco adolescentes) generaron materiales empíricos, objeto de análisis de contenido. Resultados: el alejamiento de los cambios en la imagen corporal de un adolescente sobreviviente de cáncer, el bullying y la aceptación se problematizaron en la dinámica educativa cuerpo-conocimiento a través de las relaciones entre cambios y barreras de recepción. El proceso educativo participativo fue fundamental en la sensibilización a la hora de promover acciones reinclusivas. Conclusiones: la educación participativa-problematizadora contribuyó a la construcción de una nueva identidad colectiva y al mejoramiento de la convivencia escolar entre pares.

Descriptores: Adolescente; Supervivientes de Cáncer; Enfermería Oncológica; Educación en Enfermería; Integración Escolar. 


\section{INTRODUCTION}

Cancer survival refers to the period of the first five years after the end of treatment, with many children and adolescents remaining with one or more sequelae or at least having a chronic condition in adulthood $^{(1-2)}$. In the past four decades, most childhood and juvenile cancers' survival rate has been over $80 \%$, particularly in more industrialized countries. Therefore, survival has ceased to be a rare event simultaneously. It has become an increasingly frequent reality, creating limited situations that school and hospital institutions need to learn to deal with to favor school re-inclusion of adolescent cancer survivors.

After treatment is completed, adolescents need to be fully re-included in school and social life, but there may be insufficient preparation or school support to receive cancer survivors. Among other aspects, re-inclusion becomes a multidimensional issue that involves distancing from peers and teachers, lack of information about what happened in treatment, and the reasons for the bodily changes generated by the effects of cancer treatment $t^{(3-4)}$.

The body image of any adolescent after treatment can result from multiple marks left by the type of cancer, illness, and treatment, which cut across the return to social life at school, which increases exposure to bullying. Victims of bullying can present psychosomatic manifestations, such as profound sadness, social and school phobia, the most varied types of disorders (eating anorexia, bulimia, and compulsive eating -, panic, generalized anxiety, obsessive-compulsive and post-traumatic stress), and, in the most severe cases, schizophrenia, homicide, risk of suicidal ideation and school dropout ${ }^{(5-6)}$. Therefore, avoiding that when returning to school requires intersectoral efforts to establish or reconstitute bonds between adolescents and peers, teachers, and the entire school community. All those issues require innovative and participatory educational approaches.

Both classmates and parents, teachers, and health professionals are involved in some way because they have the power to transform this reality. There is a need to redirect assistance to the quality of life of adolescents and their families, in an attempt to minimize the psychological and social, early and late effects of cancer treatment ${ }^{(7-9)}$.

Health education at school is one of the actions that favor dialogue between the two sectors (health and education) due to the ease of access the health team has to dialogue with the school to carry out health promotion activities ${ }^{(10)}$, respecting worldviews of teachers and students. The problem leads us to question: how can teachers' and students' conceptions of welcoming adolescent cancer survivors be approached in participatory educational dynamics developed in a public elementary school?

\section{OBJECTIVES}

To analyze school (re-)inclusion of an adolescent cancer survivor before/after participatory health education with adolescents.

\section{METHODS}

\section{Ethical aspects}

This research was approved in the proposing and co-participating institutions. Participants under 18 years of age confirmed their participation by signing the Informed Assent, only after their parents' authorization, through the Informed Consent, to participate in the research.

\section{Theoretical-methodological framework}

According to Paulo Freire's educational approach, nobody learns alone; learning is mediated by the experience constructed by students by immersing themselves deeply in the reality of the learning object. In this conception of education, the transitive processes of consciousness mobilize semi-transitive awareness, the naive transitive awareness and from this evolve to critic transitive awareness ${ }^{(11)}$. This immersion implies the appropriation of symbolically-mediated instruments and signs so that students are led to the borders of the proximal development zones, which is where learning takes place. The higher psychological function is only achieved when the process of awareness is interrelated to the intra-psychological formation of the learning object ${ }^{(12)}$.

Researches carried out with children and family members on caring for the child's body in chemotherapy and children with diabetes had as a starting point the experiences of caring for the body that was problematized from artistic productions ${ }^{(13-16)}$. Thus, when handling symbolic objects (the drawing of a body on a sheet of paper), the group members answer questions that rescue memories of past experiences that were internalized as part of the inter-psychological processes ${ }^{(12-16)}$. Thus, they transit through the stages of the awareness process favoring collective learning that is guided by individual narratives that are shared in a group space.

\section{Type of study}

The qualitative approach, with participatory methodology(17), was developed in field research. Among the different fields of application of participatory research, popular education is based on Freire's principles of investigation of the theme and systematization of students' previous experiences. Respect for students' values and experiences is an educator's ethical and political prerogative before starting an educational approach. In this regard, venturing into the field to explore the reality where students live, and their learning needs precedes the dialogical and participatory educational $\mathrm{act}^{(11)}$. In this research, we developed the stages of diagnosis and assessment of learning, respectively, before and after the implementation of an educational approach. As a research strategy to operationalize the principles of participatory research, the sensitive-creative method (CSM) was chosen, whose structural axis is creativity and sensitivity dynamics (CSD) (16,18-19). In this method, group interaction mediated by a question that generates debate, artistic production, and collective reflection on empirical material generated in a plural and dialogic space is prioritized.

\section{Methodological procedures}

Among the CSM dynamics, Talking Map was chosen as part of data production procedures, so that participants trace the paths taken in the community ${ }^{(16,19)}$, in the triggering of social 
relations in the territory (places) where they live and with whom (people) they live.

In addition to CSD, ethnographic records were made in the group interaction observation meetings. Her medical records and other documentation from the childhood and juvenile cancer treatment institution were consulted for information on the reference case.

Consequently, technique triangulation (CSD, observation, and consultation of medical records) allowed for greater rigor in the conduction of qualitative research, in compliance with scientific criteria - confirmability, credibility, dependability, and transferability ${ }^{(20)}$.

\section{Study setting}

Field research was implemented in a municipal school located in Rio de Janeiro city, where there was a single adolescent cancer survivor who was regularly enrolled.

\section{Data source and research participants}

The medical records provided data on the adolescent reference case that met the selection criteria, namely: a) being in the second year of cancer survival; b) having been referred by health professionals at the outpatient clinic of a reference institution for childhood and juvenile cancer treatment; c) having been recently released for a full return to school; d) presenting greater exposure to vulnerability to school inclusion; e) having been treated for a solid tumor that causes changes in body image. The reference case represented one in 333 cancer survivors monitored at the institution mentioned above, which had greater complexity and the need for intervention. It was the only case that met the selection criteria granted authorization from school and health service for research, and that also received the consent form the adolescent and her family to develop the intervention proposal. The fieldwork researcher presented the school administration's research proposal, who separately scheduled a meeting with parents and teachers. Of the 20 parents present at the meeting, 17 signed the ICF, and five adolescent students agreed to participate; of the six teachers present, two did not teach the surviving adolescent class. So, four teachers agreed to participate; therefore, nine people agreed to engage in all stages of the research: $4 / 4$ teachers who taught in the adolescent class (group), three men, aged 40, 53 and 55, teaching history, mathematics and geography; a woman, aged 41, teaching Portuguese; and 5 students/ 25 adolescents (group). This group of people was added up to the adolescent cancer survivor, totaling 10 participants.

The five adolescents in the research group also formed the group of students, three girls and two boys, aged 14 and 15, who attended the same class as the adolescent in the reference case. They were adolescent students who had varying degrees of affinity and affection for her. Two boys maintained a more friendly social relationship, two girls were superficially related to her, and one adolescent had stronger emotional ties.

The following alphanumeric code was adopted for the anonymization of participants: group $(G)$; teacher-participant $(P)$; adolescent participant (A); students (S); diagnosis (d); evaluative (e). Sequences from 1 to 5 were used to designate participant numbers.

\section{Research stages}

The diagnosis stage included information collected from the medical records of the reference case adolescent and Talking Map. Sociodemographic data, clinical data (cancer diagnosis, treatment time, physical sequelae), ambulatory follow-up, and the adolescent situation when fieldwork was being developed were extracted from the medical record. Talking Map was implemented in two meetings with two different groups of participants, generating two talking maps: one with teachers and the other with adolescents-students (20 days after school vacation).

As recommended by CSM, the field researcher followed the five moments of CSD implementation both in the group of teachers and adolescent students. In the first one, each participant introduced themselves, the objectives of the dynamics were explained, the available materials were presented (A4 paper and colored pens), and the question that generates debate was enunciated: what paths can be taken by an adolescent in postcancer treatment to have a bad/good relationship at school? In the second moment, participants designed a Talking Map (individual artistic production). In the third and fourth moments, each participant presented his/her production and critically reflected on convergent and singular themes related to cancer in adolescents, its treatment, and adverse effects, based on spontaneous conceptions of daily life. At the last moment, they synthesized different themes and subthemes, recoding them into broader themes to be addressed in educational interventions. CSD took between 40 and 50 minutes.

The educational dynamics implementation stage consisted of applying body-knowledge dynamics as a pedagogical resource, whose implementation steps are described in the results section. To problematize the inclusion of adolescent cancer survivors in school, participatory and art-based educational strategies can be productive and appropriate as an object of learning. In the set of strategies with this potential, body-knowledge dynamics stand out, primarily developed in Brazil as a research resource ${ }^{(14)}$. The creative-sensitive process of dynamics favors spaces for group interaction and knowledge exchange. Participants answer the generating question, problematize concrete existential situations, codify themes and subthemes, and recode these themes in a set of thematic syntheses that constitute new understandings on sensitive themes. Moreover, it encourages reflection and group dialog by sharing existential situations that constitute the experiences of each one during the presentation of artistic production $^{(13-16)}$.

The evaluation stage was implemented in two different periods, after implementing educational dynamics, and involved two procedures. The first period consisted of ethnographic observation of the five students who participated in Talking Map dynamics, interacting with the adolescent in the reference case. In three days (with an interval of one week) and three different environments (physical education class, in the schoolyard; Portuguese class; and recreation), there were 150 minutes of interaction events, 
120 for classes, and 30 minutes recess. All moments of observation of the participant type were previously scheduled in days and times with the teachers and the school secretary. The field researcher spent time at school on different days and hours of the school shift, allowing her presence to become familiar to the school community. The observation record was made when the observer's presence became less perceptible to the classroom dynamics, positioning herself at the back of the room or patio. For homogenizing the event records, priority was given to each person's position in the observed scene, the type of interaction, the tone of voice in verbal expressions and non-verbal body movements, etc.

After observation and the educational approach, two group meetings were held, the first with teachers (78 days) and the second with students-adolescents (93 days) who evaluated behavioral changes possibly related to the educational approach. At that time, the same materials from Talking Map prepared in the diagnostic stage were separately presented to each participant, who chose a different pen color than the one used in the diagnostic stage to add keywords and/or artistic productions that answered the question that generated debate: what do you evaluate as a change and as maintenance since the first Talking Map?

In the fieldwork, participants and researcher's engagement in CSD development, recording the observed phenomenon, and the checking by members of a research group on the generated empirical material and data analysis contributed to determine the closure of the fieldwork and clarify the possible biases of the research.

\section{Data collection and organization}

The diagnostic data included information about the diagnosis and treatment from the medical record of the adolescent cancer survivor (reference case) and the Talking Map report (from the group of adolescents and teachers), forming the first textual corpus of analysis. The data from the ethnographic observations and the report on the Talking Map's return of the evaluative stage (with the group of adolescents and teachers) constituted the second textual corpus of analysis.

\section{Data analysis}

Data were analyzed according to Bardin's content analysis ${ }^{(21)}$. In the pre-analysis stage, intelligibility and maximum completeness of communication were given, with corrections to grammar and typical language vices of colloquialisms in the Brazilian Portuguese language. Moreover, for the constitution of meanings, the text acquired linguistic materiality (with relevant scores), forming a textual corpus of analysis.

In the analysis stage, the statements were coded in context units, indexing them according to the same subject, and then separating them by indexes. Analytical frameworks were adopted for the textual corpus organization in systems of coding the units of record and units of meaning. In this way, a set of registration units was approached due to the convergence of subjects in indexes ("feelings" and "stances,"'special need," and "ignorance"), grouped into context units with the same index to extract the meanings and form primary and secondary thematic categories. Then the theoretical frameworks were applied to make the inferences, which gave light to new knowledge.

\section{RESULTS}

The results were grouped into four items: the reference case, the diagnosis of educational themes, the educational approach, and the evaluation of the pedagogical process.

\section{The reference case}

The adolescent in the reference case completed radiotherapy and chemotherapy sessions for rhabdomyosarcoma in 2015, when she was 13 years old. In February 2016, she was released to return to school after being considered cured fully. Rhabdomyosarcoma left a slight ocular protrusion due to internal residual tumoral lesion in the right eye and reduced visual acuity, hyperemia, and sclerotic edema, alopecia in the eyebrow and eyelid region, leading her to use a right eye plug. Her family enrolled her in a different school from the one she attended during the stage of becoming ill with cancer because she moved to a neighborhood on the west side of the city of Rio de Janeiro. She joined the new school that same year, where she met new colleagues and teachers. Her appearance caught everyone's attention at the new school, without people being aware of what caused it. In July 2017, when the field research was implemented, she was 15 years old and was attending elementary school at that public school.

\section{The diagnostic of educational themes}

\section{a) Body image after cancer treatment}

The visual appearance of an adolescent with an eye plug and hair covering her right orbit drew the attention of her classmates, at the same time that it generated questions to teachers about what had happened to that new girl who was beginning the school year. What was the meaning of that altered body image? The social acceptance of a stranger among peers represented a challenge for teachers who felt insecure when answering the questions asked by their adolescent students in the classroom. The beginning of coexistence at the new school was marked by anticipations, expectations, and public embarrassment.

There was a naive transient awareness of the teachers who vaguely knew that she had cancer, but did not know which type to cause this body image change. In turn, the students lived in a state of semi-transitive awareness that made them feel uncomfortable asking about it publicly. When they asked, they did so privately and directly to the teacher in the name of apparent discretion, however, in the adolescent's presence of the reference case, who attended the same class. The real reasons for the appearance of that girl remained a naive curiosity for her classmates. She was one of a stranger in the group and still unknown what had happened to her in the past.

Some students asked us [teachers] [...] they wanted to know what her problem was. I said that she had cancer for some students 
in the class who asked me in private, without going into details about why she used the eye patch because I didn't know it myself. Could the adolescent have thought, "will they accept me? Will they approve of me?". (GP2d.)

So, at first [in 2016], I had to deal with their curiosity [classmates]. They would come to my desk and ask: "teacher, that girl [points discreetly at her], what does she have?". They were discreet when asking, they spoke quietly, I believe she never noticed. (GP2d.)

I didn't know she had cancer, and I was embarrassed to ask, then she told me what she had. (GA3d.)

\section{b) Acceptance, bullying and barriers to welcoming}

Consequently, the communication noises had repercussions on adolescents' imagination, generating fear of not being accepted among peers at school, and suffering bullying (making fun). Parallel to the semi-transitive awareness of peers and the naive transitive awareness of teachers, there was a lack of school authorities' initiative to reflect on the need to promote that new student's inclusion in the school environment.

After she came to study here at school last year [2016], she was afraid the other boys in the other class would make fun of her. (GA1d.)

She didn't accept it, she thought of the boys at once, because the boys were going to make fun of her. Her girlfriends would not make fun of her. (GA2d.)

The semi-transitive and transitive naive states of consciousness produce communication barriers, anticipating being a victim of bullying, discomfort, embarrassment, and lead to withdrawal. Discomfort is a domino effect triggered by the difficulty of talking openly about the recovery from childhood cancer at school, even though adolescent cancer survivors share the same classroom environment with their peers and teachers.

In this way, both limit situations, enunciated by the dynamic Talking Map diagnosis participants, point out sensitive themes for reflection and learning at school: body image after cancer treatment, acceptance of adolescent cancer survivors, and welcoming barriers.

\section{Body-knowledge educational dynamics approach}

A week after the field investigation, a new meeting was scheduled with the same students-adolescents to address the themes, which were problematized using the body as a metaphor for their implementation of the learning strategy. In this regard, body-knowledge dynamics were chosen to be developed in four steps: preparation of the environment, the elaboration of collective artistic production, problematization (analysis and collective discussion) and outcome (thematic synthesis).

\section{Environment preparation}

The five adolescents were three girls (aged 15) and two boys (both aged 14) who attended the same class and lived in the same neighborhood as the adolescent in the reference case, a survivor of solid tumor cancer - rhabdomyosarcoma. The environment was a school classroom, a large, comfortable, airy space with good natural and artificial lighting.

The first moment, corresponding to the presentation, lasted around 10 minutes, when the researcher took on the mediator of the group in the educational process, explaining to them the form of participation in the meeting scheduled for that day. An atmosphere of welcoming and relaxation was provided, but everyone preferred to sit on the floor. All the materials used in the dynamics were available on a circle. This positioning allowed participants to look at one another during the elaboration of collective artistic production.

\section{Elaboration of collective artistic production}

Then, each one recorded on the body silhouette on $40 \mathrm{~kg} \mathrm{A4}$ bond paper, using colored pencils and colored pens, keywords or drawings to answer the triggering question of the educational process: where and how can an adolescent's body (body image) be affected by cancer (acceptance and welcoming barriers), its treatment and survival? In this second moment, a time of up to 20 minutes was reserved for the elaboration of the group production, when the group participants interacted, exchanged experiences, sought consensus and particularities related to the themes, with the material of the artistic production available in the central part of the circle of the wheel.

\section{Problematization (analysis and collective discussion)}

The third moment, with an approximate duration of 28 minutes, consisted of the presentation of the individual contribution to the collective production, at the same time that the group dialog was developed. What was registered in the artistic production was problematized (Figure 1), starting with the theme body image after cancer treatment

She came [to school] with a band on her arm. She has an armband, I already saw it; I thought it was a style thing. (GS4, boy)

What she wore was the armband. I think it was a medicine applied to the vein, which caught here [on the arm, scar from the central venous catheter]. But I didn't ask her that. She just said that there was medicine inside the band. (GS1, girl)

The production included bodily changes related to several types of childhood cancer (in the blood, lung, heart, eye, head); different treatment modalities (surgery, radiotherapy, and chemotherapy) with an amputated limb, and use of an assistive device (cane) that did not correspond to the total image presented by the adolescent they knew. About the reference case adolescent, they represented her with the eye plug (in the left orbit and not in the right) and a band on the left arm approaching the adolescent cancer survivor's image with whom they lived together at school and who aroused so much curiosity.

They collectively analyzed the body knowledge production, highlighting multiple types of cancer that can affect different organs of the body (head, right arm, right lung, the heart, blood vessels). For example, from the head-to-foot body, partial alopecia, sadness in the eyes, the purpose of the left eye plug, the use of the cane in the left hand. 


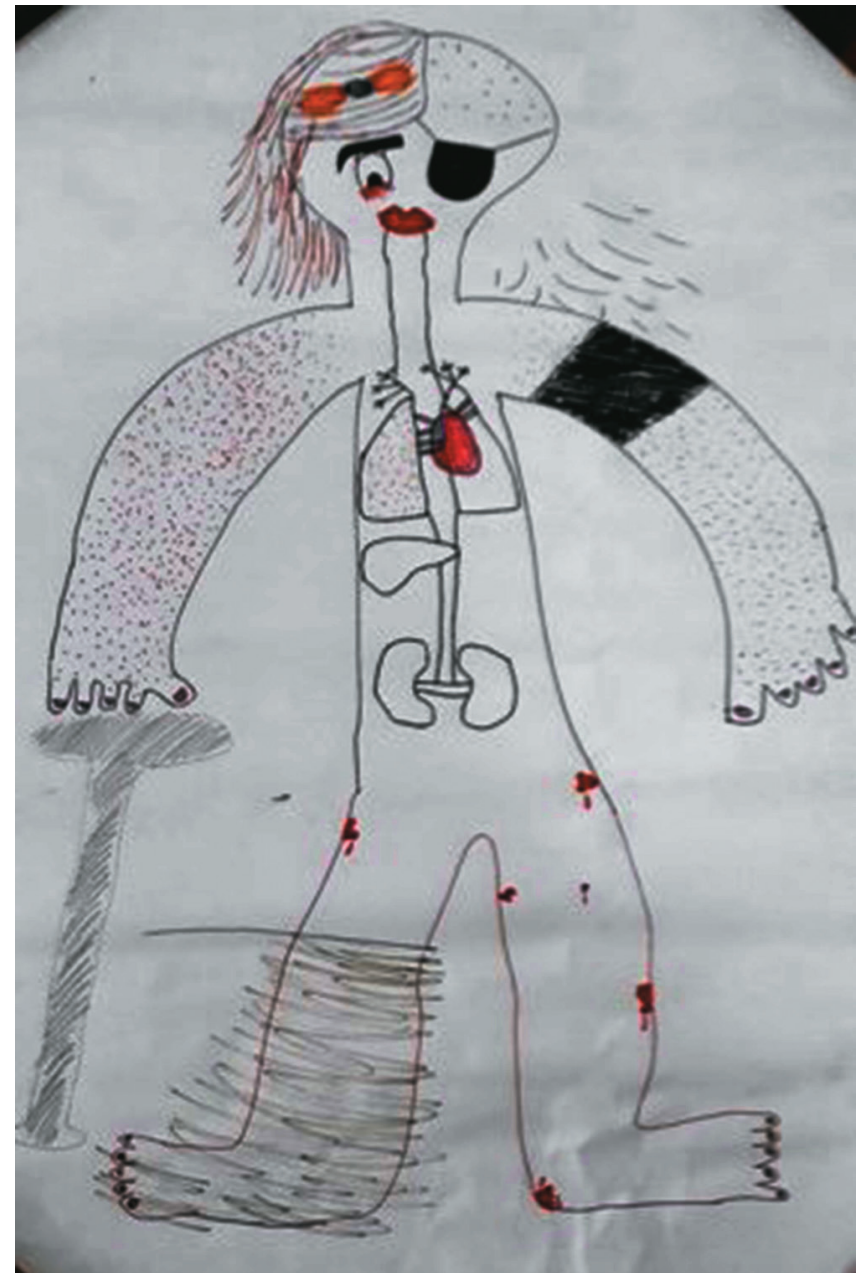

Figure 1 - Educational body-knowledge dynamics. Collective artistic production of adolescents-teachers

The effects of treatment materialized in the body's design to reflect what was seen (eye and left arm) and what was not seen (in the cardiovascular, nervous, genitourinary, hematological systems). In a dialogical movement and adopting accessible language to adolescent students' age and reality, knowledge was circulated horizontally, with artistic production mobilizing dialog and directing the construction of knowledge. The body as a metaphor provided an escape line to reflect on a theme without naming the adolescent in the reference case. The educational process problematized the metaphor of the designed body and mobilized semi-transitive awareness towards the naive transitive as a social construction; one about the changes in body image caused by becoming ill with cancer.

The acceptance of the adolescent (cancer survivor) at school depended on understanding the meaning of bodily changes. Adolescent students were unaware of the meaning of the experience of that adolescent with whom they were living.

I didn't even know, I didn't know that [armband] she had it [central venous catheter], I didn't even know her well, I had never talked to her. (GS, boy)

Last year she removed [the central venous catheter] the armband she was protecting [the catheter]. There is still the scar. (GS1, girl)
She reflected on the social and personal value of body image in adolescence, a phase of life in which the aesthetic of beauty is associated with an ideal body. However, this body can be affected by cancer and its treatment, with changes that can be early or late, transient or definitive, producing repercussions on the life of the adolescent, her family, and society.

The eye plug, the hair covering the plug, the sadness in the eyes, and the band on the left arm constitute physical barriers for accepting body image and the welcoming of the adolescent cancer survivor at school.

\section{Outcome}

In the debriefing, the three themes converged to substantive knowledge of cancer survival in adolescence. We reflected on how much chemotherapy, radiotherapy, and surgery can affect the organ systems (cardiovascular, urinary, cutaneous, and hematological) and the possible changes in the adolescent's body image due to these treatments. Artistic production was the instrument for transforming an intransitive naive conscience into a possibility that generates criticality. The metaphor body in the production was the sign that reveals the limited situation that revealed the need to change behaviors to favor inclusiveness in school, mediated by true acceptance.

In this process of awareness, the movement through the transitory stages of consciousness made everyone end that day of reflective and grateful meeting with the opportunity for dialoguing.

\section{Assessment of the pedagogical process}

In the evaluative stage, there are movements to transform student-adolescents' conceptions who participated in the group of students, after 78 days of the educational body-knowledge dynamics having been implemented. In the observation, it is clear that colleagues' relationship with the adolescent in the reference case is manifested as affectionate, welcoming, respectful, and inclusive.

Throwing the ball into the basket was in pairs. It starts with adolescent 3 , who bounces the ball on the floor and moves to adolescent 4; then this adolescent passes the ball on to the reference case adolescent. So, they take turns until the basket arrives, so that the last one can throw it. They naturally play the ball, respectfully, smiling all the time, showing pleasure and joy. (Event observed in the physical education class. Adolescent students and the reference case adolescent)

In the group meeting with the group of teachers, the artistic production of Talking Map diagnosis was presented to compare before and after participatory health education.

Now her face is completely free, completely free! I don't know if there was a change in the class [X to class $\mathrm{Y}$ ]. I believe that the change is because she must have felt more confident, based on something that happened [the educational dynamics] that we did not witness, she felt more at ease, more confident, more smiling. (GP2a)

The group reflected on the welcoming behaviors and stances of the adolescent in the reference case. A teacher pointed out that this adolescent's appearance has changed, as she has stopped 
wearing tampons and glasses, her hair no longer hides part of her face. Not only has her body image changed, but her behavior is also more self-confident and more cheerful.

In this sense, the friendly welcoming of peers produced more security in adolescents. The intersectoral mobilization between hospitals and schools seems to have improved welcoming and socio-educational inclusion. Educational body-knowledge dynamics seem to have mobilized behavior changes in the reference case adolescent, as recognized by teachers, and not only what was observed in the ethnographic record of group interaction.

The student [adolescent cancer survivor] changed the behavior of hiding the eye compromised by the disease. I don't know if the improvement was due to a new treatment or if it is related to a new stance from colleagues, after your [educational] dynamics. (GP3a.)

She improved her behavior, she is happier. (GP2a)

The adolescent in the reference case adopted a new body image (she started to no longer hide her affected orbit and eyes), which was more cheerful and self-confident. Teachers reflect on this change, associating it with self-acceptance of body image, resulting from peer acceptance.

The participatory and problematizing methodology of the educational body-knowledge dynamics played a fundamental role in constructing a new collective identity, contributing to the reconstruction of peer identity, which allowed for self-acceptance and acceptance by peers. The transitivity process of an identity consciousness was triggered by the metaphor of the problematized body in the dialogical, group, and interactive space. Adolescents who did not talk to the cancer survivor adolescent began to do so. Both in the evaluative Talking Map and the participant ethnographic observation, it appears that there were interactions and stances of mutual concern.

Her way [...] now she is [...] talkative, talking more with people, now she opens up more to people. I think she was accepting her way more, that she is no longer wearing glasses [to hide] her eye. (GA2a and GA3a)

[After the educational dynamics], her interaction with the people in the class increased [improved] a lot. Before I didn't speak, we didn't speak. Only occasionally did I speak to her. But afterwards [from the educational dynamics], we started talking more. (GA5a.)

She is seeing that she is being welcomed by more people in the class, that we are on her side for whatever happens. (GA2a.)

Here we see the journey towards the critical transitivity of conscience of another adolescent-student, who three months after the development of the body-knowledge dynamic, publicly asked for forgiveness from the survivor adolescent and encouraged the other adolescent students who exposed her to bullying to do the same.

I made a mistake with a single person at school, and I; my consciousness was heavy until that moment of educational action. I made a mistake with her, and I thought, "what did I do?"I will admit my mistake to all students in the class. Because the last time I spoke to her [after the educational dynamics], I felt that she had not sincerely and profoundly forgiven me. She remained distant; she was afraid that I would do it again, that it was not from the heart [Figure 2]; it was only lip service. It was forgiveness in words only. (GA4a)

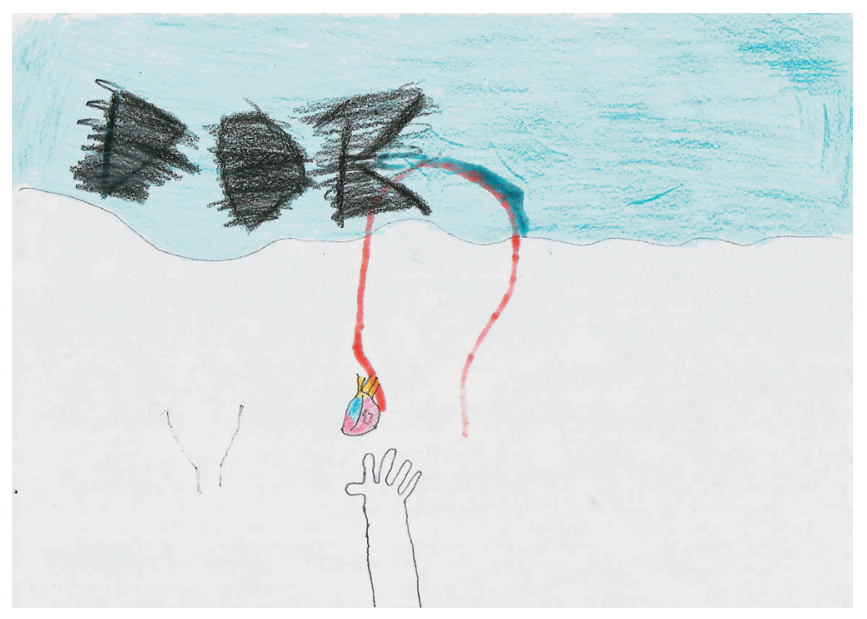

Figure 2 - GA4a artistic production. Evaluative Talking Map

This adolescent proves to himself that the knowledge built on cancer survival was not a transitory thing. He needed to consolidate it after reflecting that bullying produced a sea of pain (blue and the word pain) in the reference-case adolescent's life, which needed to be crossed out. The transitivity of his conscience generated action in the personal and collective sphere.

During the art class, I asked those who did bullying to get up, that this person would come and ask for forgiveness. I proposed this exercise to talk to Her [the adolescent] about the awful game I had played with her earlier [2016]. I got up, talked to her, and asked for forgiveness to ask for forgiveness [...] she apologizes me. From that day on, I feel better. (GA4a)

The participatory methodology of educational body-knowledge dynamics played an active role for adolescent students to move out of the purely naive sphere and assumptions about who was that different adolescent who arrived at school in 2016, to take a proactive stance of welcoming reflexivity, knowledge, and understanding. There is an opening of the awareness process, triggered by a methodology that combines participation, art, and sharing of experiences and knowledge. It started from a semi-transitive consciousness to the naive transitivity, moving towards critical transitivity. Recording bodily changes caused by cancer in a body drawn on paper was the pedagogical resource of the body-knowledge dynamics that triggered the participatory educational process.

\section{DISCUSSION}

The "limit situations" challenged the coexistence of the adolescent cancer survivor in the school context. Adolescent students and teachers problematized the acceptance of the reference-case adolescent, changes in body image, and (un)acceptance as part of the set of these situations. 
Not being aware of the reasons for the changes in body image and the new special health needs generated by the diagnosis and treatment of cancer can negatively interfere in coexistence and successful school inclusion, as analyzed in the diagnostic stage. Among the problems of re-inclusion of adolescent cancer survivors, there is a fear of the reaction of new classmates and teachers, prejudice against differences, and exposure to bullying by peers ${ }^{(5,7-8,22)}$.

The illness caused by childhood cancer was the human drama experienced by the adolescent when she entered the new school, started to live in a new neighborhood and to live with new peers, without them understanding the reasons for the appearance that did not correspond to the ideal body of someone in their teens. Adolescents live the "transition age" in which they form a new personality structure, modify and ascend to a higher level of social conduct $^{(12)}$. In this sense, depriving adolescents of returning to school is, in some way, denying them the opportunity to develop and have a complete sense of living ${ }^{(8-9)}$. The absence of welcoming initiatives in the school community can maximize these problems, leading such adolescents to withdraw from school, preventing them from ascending to a higher level of intrapsychic training.

Peers practiced bullying due to ignorance, misunderstanding, and lack of inclusive dialog promoted between the health and education sectors. As the limit situation was unveiled, the previously untried possibility of formulating new words was achieved in that same measure. These words were used between teachers, adolescent students, and the adolescent cancer survivor who overcame exclusionary behavior. According to Paulo Freire's perspective, the reading of words started to be understood from their reading of the world, unveiled in the educational and dialogical act of pedagogy inherent to educational bodyknowledge dynamics.

Awareness is a process built from inter-psychological truths that become intra-psychological ones, and that mobilize human beings to move through the stages of awareness, from semitransitive, to naïve and to critical awareness. In other words, the experience formed by instruments and signs promotes symbolic mediation capable of generating learning and transformation of consciousness $^{(11-12)}$.

In the participatory methodology of educational body-knowledge dynamics, art represented a projection of those who produced it, either in the diagnostic or in the evaluative stage. Art can project internal concepts, sometimes unknown to the person because it is a way of access to subjectivity, people can conduct discussions from the periphery to the center creatively ${ }^{(23-25)}$.

In international literature, body-mapping stands out with a similar approach to body-knowledge dynamics in addressing sensitive topics in the clinic, research, and educational practices. Both body-knowledge dynamics and body-mapping techniques mobilize participants to reflect on the relationship between body and social justice and can serve as a tool for knowledge translation, among other aspects ${ }^{(26-27)}$. It is important to address chronic conditions in adolescents and young adults, such as the engagement of adolescents and young people with type 1 diabetes mellitus in the management of their body care ${ }^{(27)}$.

The stage of implementing educational body-knowledge dynamics triggered the problematization of strangeness to changes in body image related to cancer. It seems that, initially, these changes acted as welcoming barriers for adolescent cancer survivors at school. The participatory methodology of educational body-knowledge dynamics was structured based on these assumptions to develop group work strategies. In this sense, the mediating instruments and signs of group practice can create opportunities for dialog. The participatory educational process was essential in raising awareness by promoting breaks and reinclusive actions.

If, on the one hand, development-liberation is the "unexpected possibility"; on the other hand, the "limit situation" of the governing societies is the new behavior that can be produced by the paths of education ${ }^{(11)}$. In this regard, the participatory methodology of educational body-knowledge dynamics implemented with adolescent students can influence other adolescents to develop welcoming and inclusive behaviors.

As school participation can have additional meaning for adolescents with cancer, school involvement represents a sense of normalcy and provides a sense of hope for the future ${ }^{(8)}$. After cancer treatment, returning to school can be a unique and complicated time for adolescents due to their need for development to obtain peer recognition and establish independence. After cancer treatment ends, adolescents can return to normal activities and actively participate in determining life goals and making meaningful decisions ${ }^{(6-8)}$.

The multidisciplinary team approach (with nurses and school staff) is very important to support the return of children to school $^{(6)}$. Little is known about how returning to school after cancer treatment can influence adolescents' identity and social relationships. Data on adolescents' particular perspectives are limited. Most studies have focused on the perspectives of parents, siblings, and teachers regarding the challenges that this adolescent population faces ${ }^{(3,6,8)}$.

In the evaluative stage, school coexistence changes were found after implementing the participatory methodology of educational body-knowledge dynamics, which responded to the socio-educational need of an adolescent cancer survivor with special health needs. Thus, socio-educational care represents a demand for care that this educational methodology was resolute in producing through new forms of awareness. Although the psychosocial needs are well defined (psychological, psychiatric, emotional, social, vocational, behavioral, and lifestyle), the challenge lies in providing adequate care directed to those needs ${ }^{(28)}$.

In this study, returning to school after being cured of cancer was as challenging as the experience observed during the disease, when the participatory educational process was essential in raising awareness by promoting disruptions and re-inclusive actions.

\section{Study limitations}

Participation in the participatory methodology of educational body-knowledge dynamics has not been expanded to adolescents who have not participated in the diagnostic stage, which has reduced the number of knowledge multiplier agents for the entire school community. Implementing this methodology in a single meeting with a limited number of participants and not with the whole class where the studied adolescent (reference 
case) was another limitation. Students involved in the diagnostic and evaluative stages are potential promoters of inclusion in hospital-school transition, but they also did not participate in the educational meeting.

\section{Contributions to nursing, health, and public policies}

The growing improvement in childhood cancer cure rates has provided survivors with a return to full social life and is an increasingly frequent reality. Thus, it is necessary to rethink the full educational inclusion of adolescent cancer survivors in hospital-school transition. In this process, the theme of school social coexistence should be guided by the adolescents' monitoring schedule after cancer treatment. Institutions that treat adolescents with cancer should work on establishing and strengthening the link between health and education. Likewise, sharing this knowledge and special health needs of adolescents after cancer treatment with primary care promotes an articulation between high complexity care networks with primary care. Dialog between the health and education sectors, through the Health at School Program (Programa Saúde na Escola), is necessary ${ }^{(10)}$.

Therefore, spreading health education with an approach to adolescents' social coexistence in post-cancer treatment must include school and other social spheres where adolescents transit. Full school re-inclusion represents another challenge that adds up to so many others that arise with the successful outcome of curing childhood cancer, being an intersectoral responsibility of health and education in implementing innovative approaches.

\section{FINAL CONSIDERATIONS}

Nursing action was materialized through participatory education methodology, mediated by art, reflection, and action. As an educational activity, the participatory methodology of bodyknowledge dynamics represented an open dialog between the health and education sectors, with the capacity to detect and intervene in the problems emerging from school coexistence that directly affect full school re-inclusion of adolescent cancer survivors.

In conclusion, in the implementation of the methodology, the art of collective productions became the tools and signs that trigger the awareness process, leading adolescent students to move through the stages of semi-transitive awareness to the naive transitive one, towards the possibility of expression of critical awareness. The educational approach established a cause-nexus relationship with the change in body image and mobilized feelings that led peers and adolescents (cancer survivors) to change their behaviors, moving from the abstract to the concrete field. All took on positive stances in socio-educational coexistence, as knowledge took shape, materialized in action, and re-inclusion of adolescent cancer survivors. Thus, body-knowledge dynamics generated knowledge about the body image changes produced by cancer and its treatment and understanding and relationship skills. It was an instrument that promoted improvement in school interaction among peers by welcoming adolescents in post-cancer treatment.

\section{FUNDING}

This study was financed in part by the Coordenação de Aperfeiçoamento de Pessoal de Nível Superior - Brasil (CAPES) - Finance Code 001 - with a fellowship to Camille Xavier de Mattos.

Conselho Nacional de Desenvolvimento Científico e Tecnológico (CNPQ), a research scholarship (Process Nr 303149/2019-1) and research funding (Process Nr 430213/2018-2) for Ivone Evangelista Cabral.

\section{ACKNOWLEDGEMENT}

Thanks to Professor Juliana Rezende Montenegro Medeiros de Moraes; master's student in 2016, Thais Guilherme Pimentel; Isabella da Silva Motta, Scientific Initiation fellows, all members of the Child with Special Healthcare Needs Research Group (CRIANES Research Group) for the data analysis contributions.

\section{REFERENCES}

1. Robison LL, Hudson MM. Survivors of childhood and adolescent cancer: life-long risks and responsibilities. Nat Rev Cancer. 2014;14(1):6170. doi:10.1038/nrc3634

2. Armstrong GT, Chen Y, Yasui Y, Leisenring W, Gibson TM, Mertens AC, et al. Reduction in late mortality among 5-year survivors of childhood cancer. N Engl J Med. 2016;374(9):833-42. doi: 10.1056/NEJMoa1510795

3. Soejima T, Sato I, Takita J, Koh K, Maeda M, Ida K, et al. Support for school reentry and relationships between children with cancer, peers, and teachers. Pediatr Int. 2015;57(6):1101-7. doi: 10.1111/ped.12730

4. World Health Organization. Cancer in children[Internet]. 2018[cited 2020 Jan. 02]. Available from: https://www.who.int/news-room/factsheets/detail/cancer-in-children. 2018

5. Santos MM, Perkoski IR, Kienen N. Bullying: atitudes, consequências e medidas preventivas na percepção de professores e alunos do ensino fundamental. Temas Psicol [Internet]. 2015 [cited 2020 Jan 04];23(4):1017-33. doi: 10.9788/TP2015.4-16

6. Choquette A, Rennick JE, Lee V. Back to school after cancer treatment: making sense of the adolescent experience. Cancer Nurs. 2016;39(5):393-401. doi: 10.1097/NCC.0000000000000301

7. Anders JC, Souza AIJ. Crianças e adolescentes sobreviventes ao câncer: desafios e possibilidades. Ciênc Cuid Saúde. 2009;8(1):131-7. doi: 10.4025/cienccuidsaude.v8i1.7788 
8. Helms AS, Schmiegelow K, Brok J, Johansen C, Thorsteinsson T, Simovska V, et al. Facilitation of school re-entry and peer acceptance of children with cancer: a review and meta-analysis of intervention studies. Eur J Cancer Care. 2016;25(1):170-9. doi: 10.1111/ecc.12230

9. Freitas NB, Santos JLF, Estanislau AM, Palitot RM, Fonsêca PN. As percepções das crianças e adolescentes com câncer sobre a reinserção escolar. Rev Psicopedag [Internet]. 2016 [cited 2020 Jan 4];33(101):175-83. Available from: http://pepsic.bvsalud.org/pdf/psicoped/ v33n101/07.pdf

10. Brasil EGM, Silva RM, Silva MRF, Rodrigues DP, Queiroz MVO. Adolescent health promotion and the School Health Program: complexity in the articulation of health and education. Rev Esc Enferm USP. 2017;51:e03276. doi: 10.1590/S1980-220X2016039303276

11. Freire P. Conscientização: teoria e prática da libertação: uma introdução ao pensamento de Paulo Freire. São Paulo: Cortez \& Morales, 1979.

12. Vigotski LS. A formação social da mente: o desenvolvimento dos processos psicológicos superiores. 7 aed. São Paulo: Martins e Fontes, 2007.

13. Silva LN, Silva LF, Goes FGB, Machado MED, Paiva ED. Orientações sobre quimioterapia junto à criança com câncer: método criativo sensível. O Braz J Nurs. 2015;14(suppl.):471-80. doi: 10.17665/1676-4285.20155310

14. Alvim NAT, Ferreira MA, Cabral IE, Almeida Filho AJ. O uso de plantas medicinais como recurso terapêutico: das influências da formação profissional às implicações éticas e legais de sua aplicabilidade como extensão da prática de cuidar realizada pela enfermeira. Rev LatinoAm Enfermagem. 2006;14(3):316-323. doi: 10.1590/S0104-11692006000300003.

15. Queiroz MVO, Brito LMMC, Pennafort VPS, Bezerra FSM. Sensitizing children with diabetes to self-care: Contributions to educational practice. Esc Anna Nery. 2016;20(2):337-43. doi: 10.5935/1414-8145.20160046

16. Cabral IE, Moraes JRMM. Family caregivers articulating the social network of a child with special health care needs. Rev Bras Enferm. 2015;68(6):1078-85. doi: 10.1590/0034-7167.2015680612i.

17. Streck DR. Participatory research methodologies and popular education: reflections on quality criteria. Interface (Botucatu). 2016;20(58):537-47. doi: 10.1590/1807-57622015.0443

18. Cabral IE, Neves ET. Pesquisar com o método criativo e sensível na enfermagem: fundamentos teóricos e aplicabilidade. In: Lacerda MR, Costenaro RGS (Orgs). Metodologias da pesquisa para a enfermagem e saúde: da teoria à prática. Porto Alegre: Moriá; 2016, p. 325-50.

19. Silveira A, Neves ET. The social network of adolescents who need special health care. Rev Bras Enferm. 2019;72(2):442-9. doi: 10.1590/0034-7167-2018-0543

20. Morse JM. Critical analysis of strategies for determining rigor in qualitative inquiry. Qual Health Res. 2015;25(9):1212-22. doi: 10.1177/1049732315588501

21. Bardin L. Análise de conteúdo. Lisboa: Edições 70;2016.

22. Winterling J, Jervaeus A, Sandeberg Ma, Johansson E, Wettergren L, Perceptions of school among childhood cancer survivors: a comparison with peers. J Pediatr Oncol Nurs. 2015;32(4):201-8. doi: 10.1177/1043454214563405

23. Lobo TR, Cabral IE. Concepções de professores e alunos sobre acolhimento de adolescente após o tratamento de câncer. Atas CIAIQ 2019. Invest Qualit Saúde [Internet]. 2019 [cited 2020 Jan 4];2: 956-964. Available from: : https://proceedings.ciaiq.org/index.php/CIAIQ2019/ article/view/2169

24. Pentassuglia M. "The Art(ist) is present": Arts-based research perspective in educational research. Cogent Educ. 2017;(4):1301011. doi: $10.1080 / 2331186 X .2017 .1301011$

25. McNiff S. Artistic Expressions as Primary Modes of Inquiry. British J Guid Counsel. 2011;39:385-96. doi: 10.1080/03069885.2011.621526

26. Wallace HJ, McDonald S, Belton S, Miranda Al, Costa E, Matos LC, et al. Body mapping to explore reproductive ethno-physiological beliefs and knowledge of contraception in Timor-Leste. Qualit Health Res. 2018;28(7):1171-84. doi: 10.1177/1049732317750382

27. De Jager A, Tewson A, Ludlow B, Boydell K. Embodied ways of storying the self: a systematic review of body-mapping. Forum Qualitative Sozialforschung/Forum: Qualitative Social Research [Internet]. 2016;17 (2):31p. doi: 10.17169/fqs-17.2.2526

28. Recklitis CJ, Syrjala KL. Provision of integrated psychosocial services for cancer survivors post-treatment. Lancet Oncol. 2017;18(1):e39-e50. doi: 10.1016/S1470-2045(16)30659-3 